\title{
KORIŠTENJE INTERNETA U STARIJOJ DOBI: JE LI VAŽNO ZA USPJEŠNO STARENJE?
}

\author{
Marina Nekić \\ Odjel za psihologiju, Sveučilište u Zadru \\ Obala kralja Petra Krešimira IV br. 2, 23000 Zadar \\ marina@unizd.hr \\ Ivana Tucak Junaković \\ Odjel za psihologiju, Sveučilište u Zadru \\ Obala kralja Petra Krešimira IV br. 2, 23000 Zadar \\ itucak@unizd.hr \\ Neala Ambrosi-Randić \\ Sveučilište Jurja Dobrile u Puli \\ Zagrebačka 30, 52100 Pula \\ nambrosi@unipu.hr
}

\begin{abstract}
Sažetak
Internet predstavlja široku arenu mogućnosti u kojoj starije osobe mogu dobiti adekvatnu socijalnu potporu. Strana istraživanja jasno pokazuju da IKT pomaže starijima u održavanju komunikacije s članovima obitelji i prijateljima te da može pomoći i u održavanju psihofizičkog zdravlja. Kako je uspješno starenje višedimenzionalni konstrukt koji uključuje brojne determinante, poput učenja novih stvari, tako korištenje interneta može biti važan čimbenik bolje prilagodbe promjenama koje starenje donosi. Stoga je cilj ovog istraživanja bio utvrditi u kojoj mjeri osobe starije od 60 godina koriste internet i mogu li se individualne razlike u procjeni uspješnosti starenja objasniti korištenjem interneta. U istraživanju je sudjelovalo 295 osoba u dobi između 60 i 89 godina iz različitih županija u Republici Hrvatskoj. Od mjernih instrumenata je korištena Skala samoprocjene uspješnog starenja, dok su ostali konstrukti bili zahvaćeni sa po jednom tvrdnjom, što je slučaj i u drugim sličnim istraživanjima (učestalost korištenja interneta, subjektivna dob, tjelesno i mentalno zdravlje). Dobiveno je da $40 \%$ osoba starije životne dobi koristi internet u prosjeku jednom tjedno, i to najviše za potrebe čitanja vijesti i ostalih zanimljivosti kao i za komunikaciju s članovima obitelji i prijateljima. Sudionici koji koriste internet su kronološki mlađi, sebe doživljavaju
\end{abstract}

Zahvala: Autorice zahvaljuju Elizabeth A. Phelan na korisnim sugestijama i mogućnosti korištenja njezinih materijala u svrhu ispitivanja uspješnog starenja. 
mlađima, obrazovaniji su, boljeg su tjelesnog i mentalnog zdravlja, i procjenjuju da se bolje prilagođavaju promjenama koje starenje donosi, odnosno da uspješnije stare. Nije utvrđen značajan samostalan doprinos učestalosti korištenja interneta uspješnom starenju, nego je taj odnos posredovan dobrim tjelesnim i mentalnim zdravljem i procjenom sudionika da su mlađi nego što kronološki jesu.

Ključne riječi: internet, starije osobe, uspješno starenje

\section{UVOD}

Gornja dobna granica osoba koje koriste informacijske i komunikacijske tehnologije (IKT) sve više raste, odnosno povećava se broj osoba starijih od 60 koje koriste IKT. Do 2025. godine u državama EU možemo očekivati da će preko $20 \%$ stanovništva biti starije od 60 godina. Uz ove demografske promjene i razvoj IKT vidljivo je da u zadnjih nekoliko godina ova dva područja postaju predmet istraživanja znanstvenika iz različitih područja tehnologije, zdravstvenih studija, gerontologije, psihologije i sl. Stoga se u literaturi može naići na već uvriježeni naziv, "srebrni surferi”, kojim se opisuju osobe starije životne dobi koje koriste IKT. Prema Eurostat (2016) podacima, vidljiv je trend da u nekim razvijenijim zemljama Europske unije bar svaka druga osoba starija od 64 godine pripada skupini "srebrnih surfera". Xavier i sur. (2014) potvrđuju navedene nalaze, i za Veliku Britaniju, te ističu da preko $50 \%$ starijih, u dobi između 65 i 74 godine, ima pristup internetu u svom domaćinstvu.

Unatoč rastućem broju starijih koji koriste internet, i dalje među zemljama EU postoje značajne razlike. Primjerice, u skandinavskim državama, Velikoj Britaniji i Nizozemskoj postotak starijih koji su online je između 68 i $84 \%$, dok je, nažalost, Hrvatska, na začelju, te broji svega 15\% "srebrnih surfera" (Eurostat, 2016).

Opravdanost istraživanja korištenja IKT i razvijanje programa za digitalnu pismenost starijih je od višestruke važnosti i koristi. Općenito, moderna tehnologija može biti od pomoći starijima jer im omogućuje da održe ili unaprijede vještine, da se povežu i održavaju kontakt s članovima obitelji i prijateljima, da dođu do potrebnih informacija i vijesti, ali i da se zabave. Naime, prema rezultatima nekih studija starije osobe koje koriste internet imaju bolje socijalne resurse, te stoga ne čudi što je jedan od najčešćih razloga korištenja IKT održavanje komunikacije s članovima obitelji i dobivanje socijalne potpore. Dobitak koji stariji mogu imati ako koriste internet nije samo u boljim socijalnim resursima, nego i u prevenciji demencije (Almeida, Yeap, Alfonso, Hankey, Flicker i Norman, 2012). Nakon osmogodišnje longitudinalne studije, u kojoj su Xavier i sur. (2014) pratili preko 6000 osoba u dobi od 50 do 89 godina, utvrđeno je da digitalna pismenost kod starijih može poboljšati pamćenje. Zanimljivo je da su analize dobivenih podataka pokazale da je digitalna pismenost imala značajan i nezavisan pozitivan efekt na kognitivno funkcioniranje i kada su se kontrolirale varijable poput dobi i socioekonomskog statusa. Još jedna longitudinalna studija na umirovljenicima u SAD-u upućuje na važnost digitalne 
pismenosti i korištenja interneta za mentalno zdravlje starijih. Cotten, Ford, Ford i Hale (2014) su na temelju longitudinalnog praćenja osoba starije životne dobi utvrdili da korištenje interneta smanjuje vjerojatnost pojave depresivnih stanja za oko 33\%. Najveći efekt korištenja interneta na smanjenje depresivnih stanja bio je među starijima koji su živjeli sami, što upućuje na zaključak da se vjerojatno kroz mehanizme korištenja interneta depresivna stanja smanjuju jer se reducira osjećaj socijalne izolacije i usamljenosti.

Iako se često za korištenje interneta u mlađim dobnim skupinama vežu i negativne posljedice, poput tzv. ovisnosti o internetu (Breslau, Aharoni, Pedersen i Miller, 2015; Davis, 2001), u razdoblju starije odrasle dobi internet može biti pogodan prostor za ostvarivanje komunikacije i neovisnosti osobito ako je riječ o starijim osobama koje su odvojene od članova obitelji i prijatelja, ili koje su slabo pokretljive. Stoga se može, na temelju rezultata ranije spomenutih studija, pretpostaviti da bi održavanje psihofizičkog zdravlja kroz aktivno korištenje IKT mogao biti jedan od presudnih faktora za unaprjeđenje uspješnijeg starenja.

Naime, koncept uspješnog starenja uključuje ne samo očuvanje nego i daljnje razvijanje potencijala i sposobnosti, kao i novih vještina. U kontekstu korištenja IKT, digitalna pismenost može biti jedan od aspekata uspješnog starenja.

S obzirom na to da na hrvatskoj znanstvenoj sceni nedostaju istraživanja o korištenju interneta kod starijih i utvrđivanja eventualne dobiti koje bi ta aktivnost imala, sukladno tome, cilj ovog istraživanja bio je utvrditi u kojoj mjeri osobe starije od 60 godina koriste internet, te procjenjuju li zaista "srebrni surferi" u Hrvatskoj svoje starenje uspješnim. U skladu s tim, glavni problem istraživanja bio je utvrditi mogu li se individualne razlike u uspješnom starenju pojasniti učestalošću korištenja interneta. Pritom je važno istaknuti da je dodatni cilj istraživanja bio utvrditi razlikuju li se korisnici i nekorisnici interneta u procjeni tjelesnog i mentalnog zdravlja, procjeni subjektivne i komparativne dobi, te uspješnog starenja. Naime, u kontekstu uspješnog starenja valja kazati da je u razvojnim istraživanjima uz kronološku dob, kao osnovnu varijablu, često neophodno uzeti i procjenu koliko se starima sudionici istraživanja osjećaju, odnosno procjenu subjektivne dobi. Razlog zbog kojeg je važno obje varijable uzeti u obzir, dakle, i kronološku i subjektivnu dob, vidljiv je u rezultatima studija koje jasno pokazuju da kronološka dob nije dovoljna da bi se pojasnile veze dobi i ostalih korištenih varijabli, poput uspješnog starenja ili dobrobiti (Novoselić i Tucak Junaković, 2014).

\section{METODA}

\section{Sudionici i postupak}

U ovom istraživanju sudjelovalo je 295 starijih osoba u dobi između 60 i 89 godina iz različitih dijelova Hrvatske. Prosječna dob sudionika iznosila je 69,45 godi- 
na $(\mathrm{sd}=7,01)$. Od ukupnog broja sudionika, uzorak ovog istraživanja je činilo 126 $(42.7 \%)$ muškaraca prosječne dobi $69.56(\mathrm{sd}=7,14)$, dok je žena bilo $169(57,3 \%)$ s prosječnom dobi od $69.37(\mathrm{sd}=6,94)$. Najveći broj sudionika, njih $145(49,1 \%)$, ima završeno srednjoškolsko obrazovanje, dok $92(31,2 \%)$ ima završeno osnovnoškolsko obrazovanje, i tek $58(19,7 \%)$ sudionika je završilo višu odnosno visoku školu. Što se tiče bračnog statusa, u najvećem broju su sudionici koji su u braku $(184 ; 62,4 \%)$, ostali dio uzorka čine udovci/e $(76 ; 25,8 \%)$, zatim razvedeni $(18$; $6.1 \%)$, dok je najmanje samaca $(11 ; 3.7 \%)$ i onih sudionika koji žive u nevjenčanoj zajednici (6; 2\%). Bar jedno dijete ima 277 (94,9\%) sudionika. Valja naglasiti da su uzorak ovog istraživanja činili sudionici koji žive izvan institucija, u mirovini (230; $78 \%$, dok su ostali nezaposleni ili rade), i iz grada ili manjeg mjesta $(207 ; 70,2 \%)$.

Sudionike za istraživanje regrutirali su sami istraživači, te studenti viših godina studija psihologije Sveučilišta u Zadru po principu snježne grude. Primjena upitnika bila je individualna, pri čemu su sudionici sami ispunjavali upitnik u prisutnosti ispitivača ili su ispitivači čitali pitanja i tvrdnje upitnika sudionicima (ako bi se oni odlučili za tu opciju, takvih je bilo manje od 10\%). Nakon što su sudionici završili s ispunjavanjem upitnika, svaki upitnik bio je spremljen u zasebnu kuvertu. Ukupno vrijeme koje je bilo potrebno za primjenu upitnika, iznosilo je u prosjeku 30 minuta.

\section{Mjerni instrumenti}

Tvrdnje koje se odnose na korištenje interneta osmišljene su od strane autorica te su utemeljene na sličnim istraživanjima (Eurostat, 2016; Russell, Campbell i Hughes, 2008). Dakle, učestalost korištenja interneta mjerena je jednom tvrdnjom kojoj je pridružena skala za odgovore od šest stupnjeva, gdje je broj 1 značio nikad, do 6, što je značilo svaki dan bar po nekoliko puta. Sudionici su zatim trebali procijeniti s kojim uređajem najčešće pristupaju internetu (npr. mobitel, laptop) i na kraju su trebali dati odgovor na pitanje o najčešćim razlozima korištenja interneta. Uz pitanje o najčešćim razlozima korištenja interneta, ponuđeni dogovori odnosili su se na vijesti i zanimljivosti, razgovor s rodbinom i prijateljima, igranje videoigara, društvene mreže, posao i nešto drugo (sudionici su sami trebali dopisati odgovor).

Uspješno starenje je ispitano Skalom samoprocjene uspješnog starenja (Tucak Junaković i Nekić, 2016). Skala uključuje 20 tvrdnji koje se odnose na različite aspekte uspješnog starenja, te obuhvaćaju opise koje se odnose na tjelesno i psihičko zdravlje, funkcionalno stanje i socijalno funkcioniranje (npr. "Uspješno se prilagođavam promjenama koje su povezane sa starenjem"). Sudionici su procjenjivali na skali od pet stupnjeva koliko se svaka tvrdnja odnosi na njih (od 1 - uopće se ne odnosi na mene do 5 u potpunosti se odnosi na mene). Ukupan rezultat se formira kao linearna kombinacija odgovora ili kao prosječan rezultat na cijeloj skali. Skala je u dosadašnjim istraživanjima pokazala jednofaktorsku strukturu i visoku pouzdanost (u vrijednosti od Cronbach alfa 0,87 ). 
Mjere subjektivne dobi uključivale su procjenu kognitivne dobi i komparativne dobi. Subjektivna kognitivna dob ispitana je jednim pitanjem otvorenog tipa, na temelju kojeg su sudionici trebali procijeniti koliko se starima osjećaju, bez obzira na njihovu stvarnu kronološki dob. Subjektivna komparativna dob također je mjerena jednim pitanje kao i u sličnim istraživanjima (Novoselić i Tucak Junaković, 2014). Sudionici su trebali na pitanje o tome u kojoj mjeri se osjećaju starima u odnosu na većinu ljudi njihove dobi odgovoriti na ponuđenoj skali od pet stupnjeva (1-mnogo mlađe, 2-mlađe, 3-jednako, 4-starije i 5-mnogo starije).

Procjena vlastitog tjelesnog i mentalnog zdravlja zahvaćena je sa po jednom tvrdnjom na koju su sudionici dali odgovore koristeći skalu od pet stupnjeva (1-vrlo loše, 2-loše, 3-dobro, 4-vrlo dobro i 5-izvrsno).

\section{REZULTATI}

Rezultati ovog istraživanja prikazani su slijedom od deskriptivnih parametara ispitanih varijabli na ukupnom uzorku prikazanim u tablicama 1 i 2 . U Tablici 3, prikazane su razlike između korisnika i nekorisnika interneta u kronološkoj dobi, obrazovanju, procjeni subjektivne dobi (kognitivnoj i komparativnoj), procjeni tjelesnog i mentalnog zdravlja, i u konačnici uspješnog starenja. Na kraju, u tablicama 4 i 5, prikazani su rezultati matrice korelacija ispitanih varijabli, odnosno rezultati hijerarhijske regresijske analize, s uspješnim starenjem kao kriterijem, dok su ostale ispitane varijable, zajedno s učestalošću korištenja interneta tretirane kao prediktori.

Već smo spomenuli u opisu sudionika da je prigodni uzorak ovog istraživanja uključivao starije osobe u dobi između 60 i 89 godina, odnosno s prosječnom dob od 69 godina. Sudionici ovog istraživanja osjećaju se 10 godina mlađim (M $=59,94)$, te isto tako smatraju da se osjećaju malo mlađe u odnosu na većinu ljudi njihove dobi $(\mathrm{M}=2,58)$. Tjelesno i mentalno zdravlje je procijenjeno nešto malo

Tablica 1. Prikaz deskriptivnih parametara za ispitane varijable na ukupnom uzorku $(N=295)$.

\begin{tabular}{lrcc}
\hline & $M$ & $s d$ & Raspon \\
\hline Subjektivna kognitivna dob & 59,94 & 12,97 & $23-100$ \\
Subjektivna komparativna dob & 2,58 & 0,82 & $1-5$ \\
Tjelesno zdravlje & 3,28 & 0,76 & $1-5$ \\
Mentalno zdravlje & 3,68 & 0,80 & $1-5$ \\
Učestalost korištenja interneta & 4,37 & 1,13 & $1-6$ \\
Uspješno starenje & 3,52 & 0,64 & $1-5$ \\
\hline
\end{tabular}


Tablica 2. Prikaz deskriptivnih parametara za varijable korištenja interneta na ukupnom uzorku $(N=295)$.

\begin{tabular}{|c|c|c|c|c|c|c|}
\hline $\begin{array}{c}\text { Učestalost } \\
\text { korištenja } \\
\text { interneta } \\
\end{array}$ & Nikad & $\begin{array}{l}\text { Nekoliko puta } \\
\text { godišnje }\end{array}$ & $\begin{array}{l}\text { Jednom } \\
\text { mjesečno }\end{array}$ & $\begin{array}{c}\text { Jednom } \\
\text { tjedno }\end{array}$ & $\begin{array}{l}\text { Par puta } \\
\text { tjedno }\end{array}$ & $\begin{array}{c}\text { Svaki dan } \\
\text { bar po nekoliko } \\
\text { puta }\end{array}$ \\
\hline $\mathrm{f}(\%)$ & $\begin{array}{c}176 \\
(59,7 \%) \\
\end{array}$ & $\begin{array}{c}5 \\
(1,7 \%) \\
\end{array}$ & $\begin{array}{c}11 \\
(3,7 \%) \\
\end{array}$ & $\begin{array}{c}11 \\
(3,7 \%) \\
\end{array}$ & \multirow[t]{3}{*}{$\begin{array}{c}31 \\
(10,5 \%)\end{array}$} & \multirow[t]{5}{*}{$\begin{array}{c}61 \\
(20,7 \%)\end{array}$} \\
\hline Uređaj & Mobitel & Laptop & Tablet & $\begin{array}{c}\text { Stolno } \\
\text { računalo }\end{array}$ & & \\
\hline$f(\%)$ & $\begin{array}{c}60 \\
(50,4 \%) \\
\end{array}$ & $\begin{array}{c}55 \\
(46,2 \%) \\
\end{array}$ & $\begin{array}{c}2 \\
(1,7 \%) \\
\end{array}$ & $\begin{array}{c}2 \\
(1,7 \%) \\
\end{array}$ & & \\
\hline Razlozi & $\begin{array}{c}\text { Vijesti i } \\
\text { zanimljivosti }\end{array}$ & $\begin{array}{l}\text { Razgovor s } \\
\text { rodbinom i } \\
\text { prijateljima }\end{array}$ & $\begin{array}{c}\text { Igranje } \\
\text { video- } \\
\text { igara } \\
\end{array}$ & $\begin{array}{l}\text { Društvene } \\
\text { mreže }\end{array}$ & Posao & \\
\hline$f(\%)$ & $\begin{array}{c}51 \\
(42,8 \%)\end{array}$ & $\begin{array}{c}36 \\
(30,2 \%)\end{array}$ & $\begin{array}{c}3 \\
(2,5 \%)\end{array}$ & $\begin{array}{c}26 \\
(21,8 \%)\end{array}$ & $\begin{array}{c}2 \\
(1,7 \%)\end{array}$ & \\
\hline
\end{tabular}

iznad prosjeka $\left(\mathrm{M}_{\mathrm{TZ}}=3,28 ; \mathrm{M}_{\mathrm{MZ}}=3,68\right)$, s tim da su značajno više bile procjene za mentalno zdravlje $(\mathrm{t}(294)=-8,30, \mathrm{p}=0,00)$. Sudionici ovog istraživanja procjenjuju da relativno uspješno stare, naime, prosječni rezultati su nešto iznad središnje vrijednosti $(\mathrm{M}=3,52)$.

U ovom istraživanju utvrđeno je da osobe starije životne dobi koriste internet $\mathrm{u}$ prosjeku bar jednom tjedno. Međutim, od ukupno 295 sudionika njih 59,7\% uopće ne koristi internet, dok 40,3\% sudionika koriste internet u rasponu od nekoliko puta godišnje $(1,7 \%)$ do svaki dan po nekoliko puta $(20,7 \%)$. U podskupini korisnika interneta $96,6 \%$ najčešće pristupa internetu s mobilnog telefona i laptopa, a tek u manjem broju s tableta ili stolnog računala $(3,4 \%)$. Korisnici interneta najčešće pristupaju internetu zbog čitanja vijesti i ostalih zanimljivosti na portalima, zatim zbog razgovora s prijateljima i rodbinom putem skype (programa za brzo internetsko dopisivanje, videorazgovor ili telefonski razgovor). Uz ove spomenute najčešće razloge za korištenje internata tu je još korištenje društvenih mreža poput facebooka $(21,8 \%)$, igranje videoigara $(2,5 \%)$ ili zbog posla $(1,7 \%)$.

U Tablici 3 prikazani su rezultati t-testova kojima se pokušalo utvrditi razlikuju li se sudionici koji koriste odnosno ne koriste internet po dobi, obrazovanju, subjektivnoj kognitivnoj dobi, subjektivnoj komparativnoj dobi, procjeni tjelesnog i mentalnog zdravlja te uspješnog starenja. Rezultati analiza pokazuju da su utvrđene razlike među korisnicima i nekorisnicima interneta na svim varijablama osim za subjektivnu komparativnu dob $(\mathrm{t}(294)=-3,04, \mathrm{p}=0,08)$. Naime, riječ je o tome da su korisnici interneta značajno kronološki mlađi $(\mathrm{t}(294)=-8,86, \mathrm{p}=0,00)$, ali i da se osjećaju mlađima $(\mathrm{t}(294)=-3,84, \mathrm{p}=0,00)$, te da su višeg stupnja obrazovanja $(\mathrm{t}(294)=10,43, \mathrm{p}=0,00)$. Kada je riječ o obrazovanju i korištenju interneta zanimljivo je kako je $47 \%$ nekorisnika i svega $9 \%$ korisnika osnovnoškolskog ob- 
Tablica 3. Prikaz razlika u ispitane varijablama između korisnika $(N=119)$ i nekorisnika interneta $(N=176)$.

\begin{tabular}{|c|c|c|c|c|c|c|c|}
\hline & \multicolumn{3}{|c|}{ Koriste internet } & \multicolumn{3}{|c|}{ Ne koriste internet } & \multirow[b]{2}{*}{$\mathrm{t}$-test/p } \\
\hline & $M$ & $s d$ & Raspon & $M$ & $s d$ & Raspon & \\
\hline Kronološka dob & 65,42 & 5,33 & $60-89$ & 71,99 & 6,69 & $60-88$ & $-8,86 / \mathrm{p}=0,00$ \\
\hline Obrazovanje & 2,32 & 0,62 & $1-3$ & 1,57 & 0,58 & $1-3$ & $10,43 / \mathrm{p}=0,00$ \\
\hline $\begin{array}{l}\text { Subjektivna } \\
\text { kognitivna dob }\end{array}$ & 55,76 & 12,94 & $30-100$ & 64,12 & 13,00 & $23-100$ & $-3,84 / \mathrm{p}=0,00$ \\
\hline $\begin{array}{l}\text { Subjektivna } \\
\text { komparativna dob }\end{array}$ & 2,39 & 0,76 & $1-5$ & 2,78 & 0,89 & $1-5$ & $-3,04 / p=0,08$ \\
\hline Tjelesno zdravlje & 3,49 & 0,78 & $1-5$ & 3,07 & 0,75 & $1-5$ & $4,52 / \mathrm{p}=0,00$ \\
\hline Mentalno zdravlje & 3,86 & 0,75 & $2-5$ & 3,50 & 0,85 & $1-5$ & $3,60 / \mathrm{p}=0,00$ \\
\hline Uspješno starenje & 3,84 & 0,44 & $2,45-5$ & 3,20 & 0,85 & $1-5$ & $2,87 / p=0,01$ \\
\hline
\end{tabular}

razovanja, dok je 5\% nekorisnika, ali 41\% korisnika onih koji imaju više ili visoko obrazovanje $\left(\mathrm{X}^{2}=82,40, \mathrm{p}<0,00\right)$. Iako su obje podskupine relativno dobrim procijenile tjelesno i mentalno zdravlje, ipak su procjene korisnika interneta značajno više $\left(\mathrm{t}_{\mathrm{TZ}}(294)=4,52, \mathrm{p}=0,00 ; \mathrm{t}_{\mathrm{MZ}}(294)=3,60, \mathrm{p}=0,01\right)$. Isto tako, utvrđeno je da procjenjuju značajno uspješnijim svoje starenje sudionici koji koriste internet $(\mathrm{t}(294)=2,84, \mathrm{p}=0,01)$. Kako su sudionici koji koriste internet kronološki mlađi, da bi provjerili jesu li ove dobivene razlike zaista odraz korištenja interneta ili su značajne razlike uvjetovane kronološkom dobi, proveli smo niz analiza kovarijance. Utvrđeno je da su efekti korištenja interneta za sve varijable bili značajni osim za subjektivnu komparativnu dob.

U Tablici 4 prikazane su korelacije među ispitanim varijablama, te možemo primijetiti da se veličine povezanosti kreću od niskih do umjereno visokih. Također je vidljivo da su sve varijable međusobno značajno povezane osim korelacija između kronološke dobi i subjektivne komparativne dobi $(r=0,10, \mathrm{p}>0,05)$, mentalnog zdravlja $(r=-0,09, \mathrm{p}>0,05)$ i uspješnog starenja $(\mathrm{r}=-0,04, \mathrm{p}>0,05)$.

Kako smo u ovom istraživanju uspješno starenje tretirali kao kriterijsku varijablu, prvo ćemo obratiti pozornost na povezanosti uspješnog starenja s ostalim ispitanim varijablama koje ćemo kasnije tretirati kao prediktore u regresijskoj analizi. Dobiveno je da se sudionici koji procjenjuju da uspješno stare, odnosno da se uspješno prilagođavaju promjenama koje su povezane sa starenjem, procjenjuju i mlađima u odnosu na osobe iste životne dobi $(\mathrm{r}=-0,36, \mathrm{p}<0,01)$, osjećaju se mlađima $(r=-0,42, p<0,01)$, te imaju viši stupanj obrazovanja $(r=0,13, p<0,05)$. Osim toga, uspješno starenje još je pozitivno povezano $\mathrm{s}$ tjelesnim $(\mathrm{r}=0,45, \mathrm{p}<$ 
Tablica 4. Prikaz korelacija među ispitanim varijablama $(N=295)$.

\begin{tabular}{|c|c|c|c|c|c|c|c|}
\hline & 1 & 2 & 3 & 4 & 5 & 6 & 7 \\
\hline 1. Kronološka dob & - & & & & & & \\
\hline 2. Obrazovanje & $0,31 * *$ & - & & & & & \\
\hline 3. S. komparativna dob & 0,10 & $-0,20 * *$ & - & & & & \\
\hline 4. S. kognitivna dob & $0,56 * *$ & $-0,27 * *$ & $0,60 * *$ & - & & & \\
\hline 5. Učest. koriš. interneta & $-0,45^{* *}$ & $0,51^{* *}$ & $-0,25^{* *}$ & $-0,33 * *$ & - & & \\
\hline 6. Mentalno zdravlje & $-0,09$ & $0,14^{*}$ & $-0,39 * *$ & $-0,36^{* *}$ & $0,23 * *$ & - & \\
\hline 7. Tjelesno zdravlje & $-0,17 * *$ & $0,22 * *$ & $-0,45^{* *}$ & $-0,47 * *$ & $0,28 * *$ & $0,44 * *$ & - \\
\hline 8. Uspješno starenje & $-0,04$ & $0,13^{*}$ & $-0,42 * *$ & $-0,36^{* *}$ & $0,23 * *$ & $0,46 * *$ & $0,45^{* *}$ \\
\hline
\end{tabular}

$* \mathrm{p}<.0,05, * * \mathrm{p}<.0,01$

$0,01)$ i mentalnim zdravljem $(\mathrm{r}=0,46, \mathrm{p}<0,01)$, i učestalijim korištenjem interneta $(\mathrm{r}=0,23, \mathrm{p}<0,01)$.

U odnosu na ostale ispitane varijable i njihove međusobne povezanosti, pozornost ćemo više usmjeriti na odnose između učestalijeg korištenja interneta i ostalih varijabli s obzirom na to da ostale povezanosti potvrđuju ranije nalaze sličnih istraživanja (Ambrosi-Randić i Plavšić, 2008; Kaliterna-Lipovčanin, Prizmić-Larsen i Šakić, 2002; Novoselić i Tucak Junaković, 2014).

Dakle, možemo vidjeti da je učestalije korištenje interneta u negativnoj vezi s kronološkom dobi $(r=-0,45, \mathrm{p}<0,01)$, ali i sa subjektivnom kognitivnom $(\mathrm{r}=-0,33$, $\mathrm{p}<0,01)$ i komparativnom dobi $(\mathrm{r}=-0,25, \mathrm{p}<0,01)$. Učestalije korištenje interneta pozitivno je povezano s obrazovanjem $(\mathrm{r}=0,51, \mathrm{p}<0,01)$, ali i s tjelesnim $(\mathrm{r}=0,47$, $\mathrm{p}<0,01)$ i mentalnim zdravljem $(\mathrm{r}=0,36, \mathrm{p}<0,01)$, što upućuje i na to da vjerojatno obrazovanije osobe, koje su dobrog tjelesnog i mentalnog zdravlja učestalije koriste digitalne tehnologije kao što je u ovom slučaju internet.

U zadnjoj tablici prikazani su rezultati hijerarhijske regresijske analize kojom smo htjeli utvrditi povećava li se značajno objašnjenje varijance kriterijske varijable uspješnog starenja uvođenjem učestalosti korištenja interneta. Valja kazati da se među prediktorskim varijablama nije našla kronološka dob jer se nije pokazala značajno povezanom s kriterijem $(r=-0,04, p>0,05)$. Kako su subjektivna komparativna dob i subjektivna kognitivna dob u međusobno umjereno visokoj korelaciji $(\mathrm{r}=0,60, \mathrm{p}<0,01)$, odlučili smo se da u daljnjoj regresijskoj analizi koristimo samo subjektivnu kognitivnu dob.

U Tablici 5 prikazani su rezultati dvije hijerarhijske regresijske analize s uspješnim starenjem kao kriterijem, te subjektivnom kognitivnom dobi, tjelesnim zdravljem, mentalnim zdravljem, obrazovanjem i učestalosti korištenja interneta kao prediktorima. U prvoj analizi, u prvom koraku smo uveli obrazovanje, subjektivnu 
Tablica 5. Rezultati hijerarhijske regresijske analize s uspješnim starenjem kao kriterijem, te subjektivnom kognitivnom dobi, tjelesnim zdravljem, mentalnim zdravljem, obrazovanjem i učestalosti korištenja interneta kao prediktorima.

\begin{tabular}{|c|c|c|c|c|c|}
\hline Prediktori & $\beta$ & $(\beta)$ & Prediktori & $\beta$ & $(\beta)$ \\
\hline 1. korak & & & 1. korak & & \\
\hline Obrazovanje & 0,00 & 0,04 & $\begin{array}{l}\text { Učestalost korištenja } \\
\text { interneta }\end{array}$ & $0,13^{*}$ & 0,09 \\
\hline S. kognitivna dob & $-0,20 * *$ & $-0,20 * *$ & $\begin{array}{l}\mathrm{R}^{2}=0,01 \\
\mathrm{~F}(1,293)=4,698^{*}\end{array}$ & & \\
\hline Tjelesno zdravlje & $0,24 * *$ & $0,25 * *$ & 2. korak & & \\
\hline Mentalno zdravlje & $0,27 * *$ & $0,28 * *$ & Obrazovanje & 0,04 & \\
\hline $\begin{array}{l}\mathrm{R}^{2}=0,32 \\
\mathrm{~F}(4,290)=34,138^{* *}\end{array}$ & & & S. kognitivna dob & $-0,20 * *$ & \\
\hline 2. korak & & & Tjelesno zdravlje & $0,25^{* *}$ & \\
\hline $\begin{array}{l}\text { Učestalost korištenja } \\
\text { interneta }\end{array}$ & 0,09 & & Mentalno zdravlje & $0,28 * *$ & \\
\hline$\Delta \mathrm{R}^{2}=0,01, \mathrm{p}=0,13$ & & & $\Delta \mathrm{R}^{2}=0,32, \mathrm{p}=0,00$ & & \\
\hline $\mathrm{R}^{2}=0,33$ & & & $\mathrm{R}^{2}=0,33$ & & \\
\hline $\mathrm{F}(5,289)=27,864 * *$ & & & $\mathrm{~F}(5,289)=27,864 * *$ & & \\
\hline
\end{tabular}

${ }^{*} \mathrm{p}<0,05,{ }^{*} \mathrm{p}<0,01 ;(\beta)$ - $\beta$-koeficijent u završnom koraku

kognitivnu dob, tjelesno i mentalno zdravlje, te je utvrđeno da sve prediktorske varijable, osim obrazovanja $(\beta=0,00, p>0,05)$, značajno doprinose objašnjenju uspješnog starenja $\left(\mathrm{R}^{2}=0,32, \mathrm{p}<0,01\right)$. Od pozitivnih značajnih prediktora iz prvog koraka pokazali su se tjelesno $(\beta=0,24, \mathrm{p}<0,01)$ i mentalno zdravlje $(\beta=0,27$, $\mathrm{p}<0,01$ ), dok se za subjektivnu kognitivnu dob utvrdilo da je značajan negativan prediktor $(\beta=-0,20, p<0,01)$. U drugom koraku, uvedena je učestalost korištenja interneta, te se pokazalo da ovaj prediktor, nije značajno doprinio objašnjenju varijance uspješnog starenja $(\beta=0,09, \mathrm{p}>0,05)$.

U drugoj hijerarhijskoj analizi, obrnuli smo redoslijed uvođenja prediktorskih varijabli, naime, u prvom koraku smo uveli učestalost korištenja interneta, a u drugom ostale prediktorske varijable. U prvom koraku, učestalost korištenja interneta se pokazala značajnim prediktorom $(\beta=0,13, \mathrm{p}<0,05)$, ali $\mathrm{s}$, iako značajnim, ipak zanemarivim doprinosom objašnjenju uspješnog starenja $\left(\mathrm{R}^{2}=0,01, \mathrm{p}<0,05\right)$. Uvođenjem seta prediktorskih varijabli u drugom koraku, obrazovanja, subjektivne kognitivne dobi, tjelesnog i mentalnog zdravlja, vrijednost beta pondera učestalosti korištenja interneta se smanjila i time postala neznačajna $(\beta=0,09, p>0,05)$. Ovaj rezultat upućuje na mogući medijacijski efekt subjektivne kognitivne dobi, tjelesnog i mentalnog zdravlja u odnosu između učestalosti korištenja interneta i uspješnog starenja. 


\section{RASPRAVA}

Cilj ovog istraživanja bio je utvrditi u kojoj mjeri osobe starije životne dobi koriste internet, te procjenjuju li zaista "srebrni surferi" u Hrvatskoj svoje starenje uspješnim. Među dobivenih rezultatima osnovnih deskriptivnih parametara najviše se ističe podatak da u uzorku od 295 osoba u dobi između 60 i 89 godina, njih $40 \%$ koristi internet i to u prosjeku bar jednom tjedno. Ovaj podatak je iznenađujući jer prema rezultatima istraživanja Eurostata, jasno se navodi da je Hrvatska na začelju po broju "srebrnih surfera". U tom izvješću, tek je 15\% starijih koji koriste internet, što je za $25 \%$ manje u odnosu na rezultate koje smo dobili u ovom istraživanju. Razlog tome je vjerojatno u samom uzorkovanju sudionika koji su u našem istraživanju regrutirani po principu snježne grude i predstavljaju prigodni uzorak, dok su Eurostat istraživanja utemeljena na stratificiranom uzorku. Naime, sudionici našeg istraživanja su osobe koje većinom žive u gradu ili manjem mjestu, srednje stručne spreme te dobrog tjelesnog i mentalnog zdravlja, koji se relativno dobro prilagođavaju promjenama koje donosi proces starenja i koji su još uvijek sposobni ostvariti neke svoje želje i potrebe.

Osim toga, prosječna dob sudionika je 69 godina, ali se osjećaju kao da imaju 10 godina manje. Ovi nalazi ne iznenađuju jer se već u nekoliko studija na hrvatskim sudionicima dobilo da se većina osoba starije životne dobi osjeća mlađe i sebe doživljava mlađima u odnosu na svoje vršnjake (Novoselić i Tucak Junaković, 2014; Kaliterna-Lipovčanin i sur., 2002). Nastojanje da se osoba osjeća mlađom nego što kronološki jest, prema Baraku (1987), a i nekim drugim autorima (Stephan, Caudroit i Chalabaev, 2011), način je negiranja starenja i podizanja samopouzdanja koje se percipira pozitivno jer doprinosi većoj psihičkoj dobrobiti.

Nadalje, što se tiče rezultata koji se odnose na korištenje interneta, sudionici ovog istraživanja u prosjeku koriste internet jednom tjedno. Ovaj rezultat $u$ odnosu na druga slična istraživanja u drugim zemljama, u skladu je s rezultatima istraživanja na razini država EU. Tako Eurostat (2016) rezultati pokazuju da svaka druga osoba u dobi između 65 i 74 redovito koristi internet i to bar jednom tjedno. U našem istraživanju dobili smo da korisnici interneta najčešće za pristupanje internetu koriste mobitel i laptop. U studiji koja je provedena u Velikoj Britaniji deset godina ranije, Morris, Goodmann i Brading (2007) izvješćuju da njihovi sudionici starije životne dobi većinom koriste stolna računala za pristupanje internetu.

Razlozi korištenja interneta su raznoliki, ali u najvećem postotku sudionici našeg istraživanja internet koriste za čitanje vijesti i ostalih zanimljivosti te komuniciranje s rodbinom i prijateljima. Iako su ranija istraživanja izvještavala o malom rasponu online aktivnosti starijih koji koriste internet (Loges i Jung, 2001), dok relativno novija istraživanja naglašavaju da "srebrni surferi" većinom koriste internet za komunikaciju s obitelji i prijateljima, ali i zbog drugih aktivnosti poput internet bankarstva, kupovine preko interneta i sl. Russel, Campbell i Hughes (2008) su 
utvrdili da čak 70\% sudionika njihovog istraživanja koriti internet radi komunikacije s rodbinom i s prijateljima s kojima dijele slične interese.

Vidimo da "srebrni surferi" koriste internet zbog različitih interesa i potreba, međutim ono što nismo ovim istraživanjem zahvatili jesu razlozi zbog kojih ostali sudionici ne koriste internet. Nekoliko studija ističe da su barijere korištenja interneta kod starijih isto tako brojne kao i razlozi njegova korištenja. Najčešći razlozi kod starijih osoba za nekorištenje interneta i općenito IKT su manjak interesa, osjećaj da su stari za učenje o novim tehnologijama, financijske nemogućnosti, strah od tehnologije i manjak znanja i vještina (Formosa, 2013; van Deursen i Helsper, 2015). Charness i Boot (2009) smatraju da se neke od ovih barijera mogu riješiti ako tehnologiju prilagodimo starijima, dok Butler i Baghi (2008) predlažu rješenje u kojem bi mladi mogli podučavati starije, a gdje bi obje skupine imale koristi. Tako bi mladi kroz program društveno korisnog učenja prikupili ECTS bodove, dok bi starije osobe besplatno naučile koristiti internet i računala.

Na temelju dobivenih rezultata mogli bismo reći da su korisnici interneta kronološki mlađi, te se mlađima i osjećaju. Iako imamo uzorak koji je relativno dobrog zdravlja, i tjelesnog i mentalnog, ipak se korisnici interneta smatraju zdravijima u oba područja. U skladu s tim, kako smo i očekivali, starije osobe koje koriste internet smatraju da su zadovoljnije, produktivniji socijalno uključenije odnosno procjenjuju da uspješnije stare.

Uz to što se sudionici međusobno razlikuju u ispitanim varijablama s obzirom na korištenje interneta, $\mathrm{i}$ to u "korist" korisnika interneta, također možemo vidjeti da je učestalije korištenje interneta povezano sa svim varijablama koje smo ispitivali u ovom istraživanju i to u očekivanom smjeru. Tako je dobiveno da učestalije korištenje interneta prati viši stupanj obrazovanja, odnosno da obrazovanije osobe starije životne dobi više koriste internet. Razlog tome može biti da su vjerojatno obrazovanije osobe u sklopu poslova koje su obavljale ili još uvijek obavljaju trebale naučiti vješto se koristiti IKT. Naime, rezultati upućuju na to da $91 \%$ korisnika interneta su osobe koje su završile srednju školi i višu odnosno visoku. Isto tako, jasno se vidi da i niža kronološka i subjektivna dob upućuju na učestalije korištenje interneta, ali i dobro tjelesno i mentalno zdravlje. Ovi podaci možda reflektiraju manji strah kod zdravijih, kronološki mlađih i onih koji se mlađima osjećaju prema korištenju modernih tehnologija. Helsper i Reisdorf (2013) ističu da su starije osobe koje koriste internet $\mathrm{i}$ koje ga koriste učestalo većinom obrazovanije i vjerojatno iskusnije u korištenju računala, te boljih kognitivnih i motoričkih sposobnosti (Charness i Boot, 2009; Czaja, 2005; Xie, 2003).

Uspješno starenje je u ovom istraživanju tretirano kao kriterijska varijabla, te uvidom u povezanosti s ispitanim varijablama možemo uočiti da su pozitivne povezanosti ostvarene s obrazovanjem, tjelesnim i mentalnim zdravljem i učestalošću korištenja interneta, dok su subjektivna kognitivna i komparativna dob bile u negativnoj korelaciji s uspješnim starenjem. Rezultati koji se odnose na vezu uspješnog starenja i obrazovanja, zdravlja i subjektivne dobi su i ranije dokumentirana u slič- 
nim istraživanjima (Novoselić i Tucak Junaković, 2014; Tucak Junaković i Nekić, 2016). Može se očekivati da će osobe koje procjenjuju bolje zdravstveno stanje, koje su obrazovanije (vjerojatno i boljeg socioekonomskog statusa) i koje sebe vide mlađima nego što jesu, smatrati da uspješnije stare. Tucak Junaković i Nekić (2016) ističu da se $u$ literaturi često kao faktore uspješnog starenja navode upravo faktori poput zdravlja, zadovoljstva životom, socijalna uključenost, otvorenost k učenju novih stvari, angažiranost u zajednici, doživljaj svrhe i smisla života. Korištenje interneta je oblik nove aktivnosti koje bi starija osoba mogla naučiti i koristiti u svakodnevnom života, stoga nas osobito zanima dobivena pozitivna povezanost uspješnog starenja s učestalošću korištenja interneta. Iako ove relacije do sada nisu bile zahvaćene $u$ istraživanjima, ipak smo pretpostavili da će kod starijih učestalost korištenja interneta biti ne samo povezana s uspješnim starenjem nego da će i doprinijeti objašnjenju individualnih razlika u uspješnom starenju.

Dakle, što se pak tiče doprinosa pojedinih prediktorskih varijabli uspješnom starenju, proveli smo dvije hijerarhijske analize. Sukladno postavljenom cilju istraživanja o provjeri zasebnog doprinosa učestalosti korištenja interneta u prvoj hijerarhijskoj regresijskoj analizi u prvom koraku uveli smo set od četiri prediktorske varijable, s tim da smo zbog relativno umjereno visoke korelacije između subjektivne kognitivne i subjektivne komparativne dobi odlučili daljnje analize provoditi samo subjektivnom kognitivnom dobi, obrazovanjem i tjelesnim i mentalnim zdravljem. Ovaj set varijabli zajedno je objasnio 32\% varijance uspješnog starenja, na način da je relativno najizraženiji prediktor bilo mentalno zdravlje, zatim, tjelesno zdravlje i na kraju subjektivna kognitivna dob, dok se obrazovanje pokazalo kao neznačajan prediktor. U drugom koraku uvedena je učestalost korištenja interneta, koja unatoč očekivanjima nije dodatno doprinijela objašnjenju kriterija. Očekivali smo samostalni doprinos učestalosti korištenja interneta jer su neka od prethodnih sličnih istraživanja izvijestila o tome (Stern, 2012; Xavier i sur., 2014 ).

Druga hijerarhijska analiza uključivala je obrnuti slijed uvođenja prediktora. Tako je u prvom koraku uvedena učestalost korištenja interneta, dok je drugi korak činio set varijabli iz prvog koraka prethodne hijerarhijske analize. Rezultati upućuju na to da je učestalost korištenja interneta značajan prediktor uspješnog starenja, ali s jako malim postotkom objašnjenje varijance, čija se značajnost gubi uvođenjem obrazovanja, subjektivne kognitivne dobi, i tjelesnog i mentalnog zdravlja. S obzirom na dobivene rezultate, a prema preporukama Barona i Kennyja (1986), možemo smatrati da je vjerojatno veza učestalosti korištenja interneta i uspješnog starenja posredovana dobrim tjelesnim i mentalnim zdravljem te osjećajem starijih da su mlađi nego što kronološki zaista jesu. Dakle, korištenje interneta ne doprinosi uspješnom starenju direktno, nego je za tu vezu važno da je osoba dobrog tjelesnog i mentalnog zdravlja i da sebe procjenjuje mlađom. Naime, upravo osobe koje su boljeg zdravlja i smatraju se mlađima jesu i one koje češće koriste internet.

Perez, Memeti i Pllana (2016) jasno ističu da internet za starije može biti način kako da što neovisnije i zadovoljnije žive bez obzira na zdravstveni status. U istra- 
živanju na australskom uzorku starijih, Russell, Campbell i Hughes (2008) ističu kako je internet osobito koristan starijima s kroničnim bolestima jer zbog mirovanja ili ograničenih aktivnosti, internet postaje prozor koji može spriječiti osjećaj usamljenosti i socijalne izolaciju.

Czaja (2016) smatra da je prilagodba IKT starijim osoba veliki izazov za sve, jer ne samo da se istraživači trebaju usmjeriti prema uklanjanju prepreka zbog kojih stariji slabije koriste IKT, nego se trebaju pronaći načini kako IKT može doprinijeti zadovoljnijem i ispunjenijem životu osoba starije životne dobi. Pitanje je s obzirom na očekivane razvojne promjene u svim domenama razvoja, od kognitivnih do zdravstvenih, kod osoba starije životne dobi i kontinuiranog i stalnog razvoja IKT hoće li starije kohorte moći pratiti razvoj tehnologije i kako će to utjecati na osjećaj uspješnog starenja ili opće dobrobiti.

Na kraju ako se osvrnemo na neka ograničenja ovog istraživanja, prvenstveno, osim transverzalnog nacrta, treba istaknuti korištenje mjera samoprocjene i to osobito za konstrukte koji su zahvaćeni sa po jednom tvrdnjom, te mogući problem multikolinearnosti zbog povezanosti među prediktorima. Međutim, prema nekim autorima (Gardner, Cummings, Dunham i Pierce, 1998) mjere s jednom tvrdnjom mogu, u odnosu na skale ili upitnike, biti adekvatne ako su dobro operacionalizirane, što smatramo da je u ovom radu i učinjeno. Buduća istraživanja bi svakako trebala biti multidisciplinarna i po mogućnosti longitudinalna u kojima bi se osobe starije životne dobi pratilo u više točaka mjerenja ne bi li se utvrdile eventualne dobrobiti korištenja IKT za uspješno starenje i ostale varijable psihičke dobrobiti. To bi osobito bilo zanimljivo i korisno kada bi se pratili stariji prije i nakon što su naučili koristiti IKT.

Unatoč ograničenjima ovog istraživanja koje bi mogle biti smjernice za buduća, ovo istraživanje smatramo prvim korakom u objašnjenju važnosti korištenja IKT u starijoj dobi. Očekujemo da će ova tema izazvati interes hrvatskih istraživača iz različitih područja, jer ako pratimo trendove i svjetske projekte u razvijenim zemljama, IKT i starenje postaju nezaobilazna i od praktične vrijednosti značajna multidisciplinarna područja.

\section{LITERATURA}

Almeida, O.P., Yeap, B.B., Alfonso, H., Hankey, G.J., Flicker, L. i Norman, P.E. (2012). Older men who use computers have low risk of dementia. PLoS One, 7, e44239.

Ambrosi-Randić, N. i Plavšić, M. (2008). Uspješno starenje. Pula: Društvo psihologa Istre, Istarska županija, Sveučilište Jurja Dobrile u Puli.

Barak, B. (1987). Cognitive age: A new multidimensional approach to measuring age identity. The International Journal of Aging and Human Development, 25, 109-127.

Barron, R.M. i Kenny, D.A. (1986). The Moderator-Mediator Variable Distinction in Social Psychology Research: Conceptual, Strategic, and Statistical Considerations. Journal of Personality and Social Psychology, 51, 1173-1182. 
Breslau, J., Aharoni, E., Pedersen, E. R. i Miller, L.L. (2015). A Review of Research on Problematic Internet Use and Well-Being. RAND Corporation. Santa Monica, California.

Butler, F.R. i Baghi, H. (2008). Using the Internet to Facilitate Positive Attitudes of College Students Toward Aging and Working with Older Adults. Journal of Intergenerational Relationships, 6, 175-189.

Charness, N. i Boot, W.R. (2009). Aging and Information Technology Use. Current Direction in Psychological Science, 18, 253-258.

Cotten, S.R., Ford, G., Ford, S. i Hale, T. (2014). Internet Use and Depression Among Retired Older Adults in the United States: A Longitudinal Analysis. Journal of Gerontology Series B: Psychological Sciences and Social Sciences, 69, 763-771.

Czaja, S.J. (2005). The impact of aging on access to technology. ACM SIGACCESS Accessibility and Computing, 83, 7-11.

Czaja, S.J. (2016). Long-Term Cate Service and Support Systems for Older Adults: The Role of Technology. American Psychologist, 71, 294-301.

Davis, R.A. (2001). A cognitive-behavioral model of pathological Internet use (PIU). Computers in Human Behavior, 17, 187-195.

Eurostat (2016). Digital economy and society statistics - households and individuals. http:// ec.europa.eu/eurostat/statistics-explained/index.php/Digital_economy_and_society_ statistics_-_households_and_individuals (preuzeto 10.2 2017.)

Formosa, M. (2013). Digital exclusion in later life: A Maltese case study. Humanities and Social Sciences, 1, 21-27.

Gardner, D.G., Cummings, L.L., Dunham, R.B. i Pierce, J.L. (1998). Single item Versus Multiple-Item Measurement Scales: An Empirical Comparison. Educational and Psychological Measurement, 58, 898-915.

Helsper, E.J. i Reisdorf, B.C. (2013). A quantitative examination of explanations for reasons for Internet nonuse. Cyberpsychology, behavior, and social networking, 16, 94-99.

Loges, W. E. i Joo-Young Jung (2001) Exploring the digital divide: Internet connectedness and age. Communication Research, 28, 536-562.

Morris, A., Goodman, J. i Brading, H. (2007). Internet use and non-use: views o folder users. Universal Access in the Information Society, 6, 43-57.

Novoselić, M. i Tucak Junaković, I. (2014). Odnos između subjektivne dobi i nekih sociodemografskih značajki, osobina ličnosti i zdravlja. Društvena istraživanja, 3, 489-509.

Kaliterna-Lipovčanin, Lj., Prizmić-Larsen, Z. i Šakić, V. (2002). Subjektivna dob, životno zadovoljstvo i zdravlje. Društvena istraživanja, 6, 897-908.

Perez, D.G., Memeti, S. i Pllana, S. (2016). A Study of and Internet of Things Soulution for Independent Aging. Computers and Society, https://arxiv.org/pdf/1606.02455.pdf

Russell, C., Campbell, A. i Hughes, I. (2008). Ageing, social capital and the Internet: Findings from an exploratory study of Australian "silver surfer". Australasian Journal on Ageing, 27, 78-82.

Stephan, Y., Caudroit, J. i Chalabaev, A. (2011). Subjective health and memory self-efficacy as mediators in the relation between subjective age and life satisfaction among older adults. Aging \& Mental Health, 15, 428-436. 
Stern, Y. (2012). Cognitive reserve in ageing and Alzheimer's disease. Lancet Neurology, $11,1006-1012$.

Tucak Junaković, I. i Nekić, M. (2016). Skala samoprocjene uspješnog starenja. U I. Tucak Junaković, I. Burić, V. Ćubela Adorić, A. Proroković i A. Slišković (ur.), Zbirka psihologijskih skala i upitnika, svezak 8 (str. 37-43). Zadar: Sveučilište u Zadru.

Van Deursen, A. i Helsper, E.J. (2015). A nuanced understanding of Internet use and non-use among the elderly. European Journal of Communication, 30, 171-187.

Xavier, A.J., d'Orsi, E., de Oliveira, C.E., Orrell, M., Demakakos, P., Biddulph, J.P. i Marmot, M.G. (2014). English Longitudinal Study of Ageing: Can Internet/E-mail Use Reduce Cognitive Decline? Journals of Gerontology: Medical Sciences, 69, 1117-1121.

Xie, B. (2003). Older adults, computers, and the Internet: Future directions. Gerontechnology Journal, 2, 289-305.

\title{
USING THE INTERNET IN OLDER AGE: IS IT IMPORTANT FOR SUCCESSFUL AGING?
}

\begin{abstract}
Summary
Internet presents a wide arena of possibilities in which older people can get adequate support in the domains of health and social relations. Studies clearly show that the Internet, information and communication technology help the elderly to maintain communication with family members and friends and that can help in maintaining psychological and physical health. Successful aging is a multidimensional construct that includes a number of determinants, such as learning new things, so Internet use can be an important factor for older people to better adapt to changes that aging brings. The purpose of this study was to determine the extent to which people over 60 use the Internet and whether the individual differences in successful aging could be explained by the frequency of Internet use. The study included 295 people aged between 60 and 89 years from various counties in the Republic of Croatia. The Scale of Successful Aging was used while other constructs were assessed with single-item measurements, which is the case in other similar studies (frequency of Internet use, subjective age, physical and mental health). The results show that $40 \%$ of elderly people use the Internet on average once a week, mainly for reading the news and other points of interest as well as to communicate with family members and friends. Participants who use the Internet are chronologically younger, perceive themselves as younger, more educated, have better physical and mental health and estimated that they age successfully. There was no significant independent contribution of the frequency of Internet use to successful aging, but the relationship was mediated by good physical and mental health and perception of participants that feel younger than their chronological age.
\end{abstract}

Key words: internet, older people, successful aging 
